\title{
Seminal Parameters and Sexual Behavior on Farm Rabbits Provided with a Diet Supplemented with Canola Oil at the Start of Puberty
}

\author{
Parámetros Seminales y Conducta Sexual en Conejos de Granja con \\ Dieta Suplementada con Aceite de Canola al Inicio de la Pubertad
}

Nancy Guadalupe Mejía Huerta ${ }^{1}$; Jorge Hernández Espinosa ${ }^{1}$ \& Mario Pérez-Martínez ${ }^{1}$

MEJÍA, H. N. G.; HERNÁNDEZ, E. J. \& PÉREZ-MARTÍNEZ, M. Seminal parameters and sexual behavior on farm rabbits provided with a diet supplemented with canola oil at the start of puberty. Int. J. Morphol., 36(1):59-62, 2018.

SUMMARY: In order to evaluate the effect on sexual behavior and spermatic parameters of white New Zealand rabbits, at the onset of puberty, they were fed a standard diet supplemented with canola oil (obesogenic). Two groups were formed; one of which received daily $180 \mathrm{~g}$ of a standard commercial diet supplemented with $13 \mathrm{ml}$ of canola oil during 12 weeks, while the second group (control) were fed daily $180 \mathrm{~g}$ of only the standard commercial diet. Starting at 20-weeks of age, seminal volume, en masse and individual sperm motility, and sperm concentration per $\mathrm{mm}^{3}$ were measured from each individual, as well as the behaviors olfactory exploration, chinning, and first and second attempt at mounting were assessed. No significant differences were found between groups in terms of seminal volume, and en masse and individual sperm motility count and percentage $(\mathrm{P}>0.05)$. In relation to sexual behavior, the group fed with supplemental canola oil showed reduced the response time to females in the sexual behaviors of chinning, olfactory exploration, and first and second attempt at mounting when compared to the control group $(\mathrm{P}<0.01)$. The data indicate that the addition of canola oil to a standard rabbit diet at the start of puberty and continued for 12 weeks increases the body mass index and reduces the response time in sexual behaviors such as olfactory exploration, chinning, and second attempt at mounting when interacting with female stimulus. Nevertheless, the seminal parameters did not show any modification. Other studies are needed to show the benefits or disadvantages of the addition of varying inclusion percentages of other vegetable oils, to evaluate their effects on reproductive efficiency in breeder male rabbits.

KEY WORD: Farm rabbit; Puberty; Semen; Sexual behavior; Canola oil.

\section{INTRODUCTION}

An overweight or obese state is characterized by the progressive accumulation of fatty tissue in the body due to an energy imbalance between calories consumed and used, which over time has serious effects on individuals (Fitzgerald et al., 2001). Domestic rabbits have been used as an animal model for the study of various pathologies related with altered lipid metabolism in humans (Zhang et al., 2008).

Sexual behavior and reproductive cycle in the domestic rabbit under animal care facility conditions has been thoroughly described in literature (Jiménez et al., 2012). Nevertheless, there are few studies on the reproductive characteristics of farmed rabbits at the start of puberty (Fuentes et al., 2004). To the best of our knowledge, there are no studies on farm rabbits, during the onset of puberty, in which the effect of diet on testicular function and sexual behavior has been assed. In light of this, the purpose of this study was to evaluate the effect of a diet supplemented with canola oil (obesogenic) on seminal parameters and sexual behavior at the onset of puberty, in New Zealand rabbits under farm conditions.

\section{MATERIAL AND METHOD}

The study was carried out in the rabbit breeding section of the Centro de Enseñanza, Investigacion y Extension de la Universidad Nacional Autonoma de Mexico, located in Delegacion Tlahuac, Mexico City which is at 2250 momsl. This area has a sub-humid temperate climate with an annual mean temperature of $16^{\circ} \mathrm{C}$. Throughout the study all efforts were undertaken to minimize animal suffering and the number of animals used. The study was approved by the Internal 
Committee for the Welfare and Use of Animals of the Faculty of Veterinary Medicine and Animal Husbandry of UNAM.

A total of 18 clinically healthy, male, 15-week-old, white New Zealand breed rabbits (Oryctolagus cuniculus) with a mean weight of $2.8 \mathrm{~kg}$, were used. Animals were kept in individual cages within housing with controlled ventilation and light-darkness hours (16 hours light, 8 hours darkness). Animals were randomly placed into one of two groups ( $\mathrm{n}=9 /$ group) and allowed to acclimatize for two weeks prior to the start of the experiment. After this time, one group received an obesogenic diet that consisted of $180 \mathrm{~g} /$ day of a standard commercial diet in pellets $(15.5 \%$ minimum protein, 15.0 $\%$ minimum fiber, $2 \%$ minimum fat) supplemented with 13 $\mathrm{ml}$ of commercial canola oil (for human consumption), while the control group only received the standard commercial diet. Feed was provided in individual troughs for 12 weeks; water was provided ad libitum.

Body mass index (BMI) was calculated according to the criteria used in cats (Nelson et al., 1990; Appleton et al., 2001). BMI was determined every seven days by weighing all individuals and measuring them, with a flexible measuring tape, their height (distance between the dorsal edge of the scapula and the proximal phalange of the thoracic member) and body length (distance between the dorsal edge of the scapula and the ischium tuberosity). Also, every seven days a drop of blood was obtained from the lateral auricular vein (prior 12 hour fasting) using a lancet in order to measure glucose concentration $(\mathrm{mg} / \mathrm{dL})$ with an automated glucometer (CONTOUR TS®).

Starting from 20 weeks of age, every seven days (4 samplings), semen was obtained from each individual in both groups using an artificial vagina, and the volume of the first ejaculate was determined (Alcántar, 2013). Evaluation of en masse motility was carried out with undiluted semen placed on a glass slide and observed under the 40x objective (Motic BA310®) of the optical microscope; rotation, linear progressive and/or circular movements were recorded. In order to evaluate individual motility, semen was diluted using an isotonic solution at $38^{\circ} \mathrm{C}$ in a $0.5 \mathrm{ml}$ volume. A drop was placed on a glass slide and progressive linear movement of sperm was recorded. A Neubauer chamber was used to de- termine sperm concentration per $\mathrm{mm}^{3}$ (Alvariño, 2000; Rebollar, 2006).

In parallel to semen evaluation, sexual behavior was recorded for individuals in each group, every 7 days (4 evaluations). A young New Zealand female, weighing $3 \mathrm{~kg}$, without previous sexual experience was used as stimulus by introducing it into the cage of each adult male. Male-female interactions were recorded during 5 minutes (Villagrán et al., 2003). A concrete cube was placed inside each cage in order to visualize the chinning behavior of males. Sexual behavior was recorded using a video digital camera. The behaviors to be evaluated were: a) olfactory exploration, b) chinning, c) first attempt at mounting, and d) second attempt at mounting. Evaluation of sexual behavior was carried out on a day different from the day semen was obtained, in order to reduce as much as possible the stress of animals due to handling.

Variables (seminal parameters and sexual behavior) were compared between groups (Standard diet supplemented with canola oil vs standard diet only) using Mann-Whitney's U-test. Data shown as mean \pm SEM. Values of $* \mathrm{P} \leq 0.05$, $* * \mathrm{P}<0.01$ were considered statistically significant.

\section{RESULTS}

At the end of the study, individuals that had received the diet supplemented with canola oil attained a higher BMI than individuals in the control group (37.6 \pm 0.6 vs $40.9 \pm$ $0.9 ; \mathrm{P}<0.001)$. It is important to state that the amount of canola oil used in the diet did not cause any mechanical upset of the digestive function. No significant differences in plasma glucose concentration were found between groups during the first four weeks of the experiment $(\mathrm{P}>0.05)$. Nevertheless, in weeks 5 and 9, the group that received the diet supplemented with canola oil had higher plasma glucose concentrations when compared with the control group (91.08 \pm 1.03 vs $88.45 \pm 1.31 \mathrm{mg} / \mathrm{dL} ; \mathrm{P}<0.01)$.

No significant differences between groups $(\mathrm{P}>0.05)$ were found in seminal volume, sperm concentration and sperm in masse and individual motility percentage (Table I).

Table I. Seminal parameters of rabbits fed with a diet supplemented with vegetable OIL*

\begin{tabular}{lcc}
\hline & Standard diet & Diet supplemented with vegetable OIL \\
\hline & Mean \pm SEM & Mean \pm SEM \\
Seminal volume $(\mathrm{ml})$ & $0.75 \pm 0.69$ & $0.89 \pm 0.10$ \\
En masse sperm motility $(\%)$ & $85.20 \pm 0.92$ & $80.55 \pm 2.05$ \\
Sperm concentration $(106 / \mathrm{ml})$ & $541.37 \pm 53.63$ & $571.11 \pm 55.49$ \\
Individual sperm motility $(\%)$ & $77.5 \pm 1.24$ & $75.27 \pm 2.78$ \\
\hline
\end{tabular}

*No statistical difference between groups $(\mathrm{P}>0.05)$. 
Moreover, the group that received supplementation with oil showed reduced response time to the stimulus female regarding chinning behavior, olfactory exploration and second attempt at mounting, when compared to the control group $(\mathrm{P}<0.01)$ (Fig. 1).
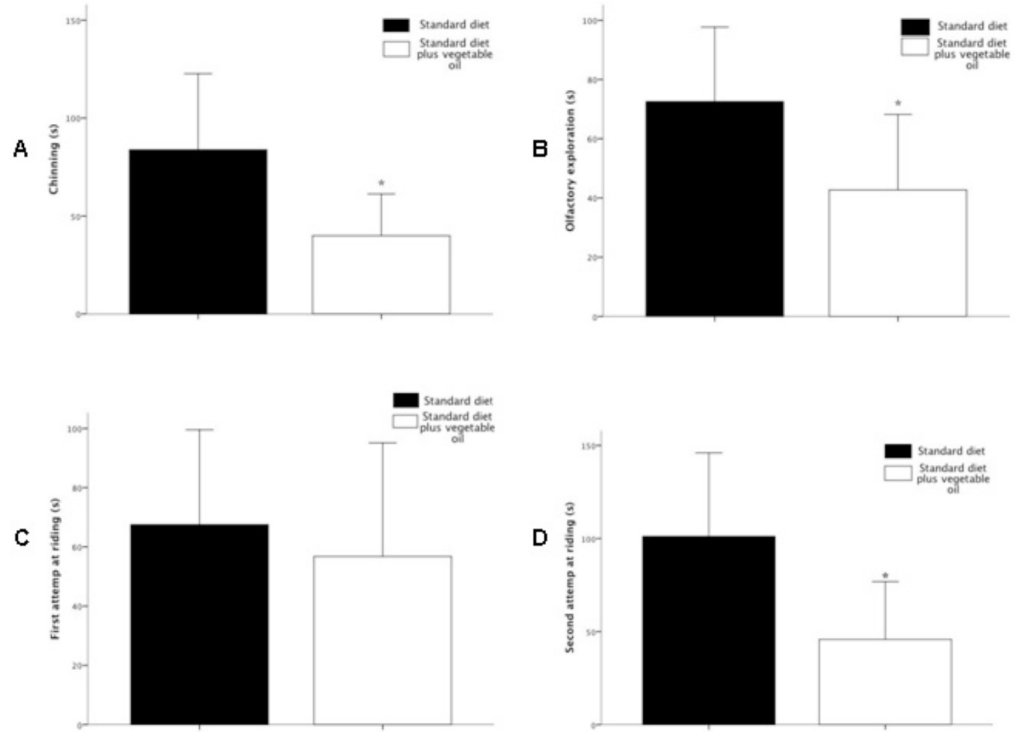

Fig. 1. Male response time (seconds) to the stimulus female in terms of: A) Chinning, B) Olfactory exploration, C) First attempt at riding, and D) Second attempt at riding. Standard diet supplemented with canola oil vs standard diet only. Data shown as mean $\pm \mathrm{SEM}, * \mathrm{P}<0.01$; Mann-Whitney’s U-test.

\section{DISCUSSION}

Males from the group fed with a diet supplemented with oil had a reduced response time when interacting with the stimulus female in terms of olfactory exploration, chinning and second attempt at mounting. This suggests that the higher energy levels provided by the supplemented diet favored the manifestation of sexual behavior. It is important to note that the stimulus provided by the sexually naive $3 \mathrm{~kg}$ female was sufficient to induce sexual interest in males. A previous study stated that New Zealand females weighing $3 \mathrm{~kg}$ in pubertal transition state show notable development of the uterus and ovarian follicles (Aragón Hernández et al., 2010). Sudden changes in the energy equilibrium of individuals modify the reproductive function at the hypothalamus-hypophysis-testicle pathway (Ristic et al., 2016). Fatty tissue is an important source for the leptin hormone, and the increase or decrease in its secretion has an important influence on the neuro-endocrine system that regulates reproductive function (Caprio et al., 2001; Moschos et al., 2002), the onset of puberty (Caprio et al.; Moschos et al.), and the regulation of the energy balance in the individual (Trayhurn \& Bing, 2006).

At the end of the study, rabbits that had received the diet supplemented with canola oil reached a higher BMI than the control group. As it is well known, a high consumption of lipids in diet favors the depositing of triglycerides in fatty tissue, which causes an increase in body weight (Schrauwen \& Westerterp, 2000).
The discrete increase in glucose levels in blood, in weeks 5 and 9, in the group with oil-supplemented diet, indicates that the method used for its measurement was sensitive and allows fine monitoring of glycaemia related to diet. Current literature regarding the variations in glucose concentration in blood of domestic rabbits in relation to diet is scarce and the various reference values presented in them show important differences between them (Campbell, 2004; Jenkis, 2006; HarcourtBrown \& Harcourt-Brown, 2012). There is a direct relationship between blood glucose concentration and food ingestion. The hypothalamus has leptin receptors that participate in the regulation of glucose homeostasis (Coppari et al., 2005).

The fact that no significant differences were found between groups in the seminal parameters in this study does not exclude the possibility that the fertilization capacity of sperm could be affected due to a high inclusion of oil in the diet. As such, it is necessary that future studies determine the fertility index in male rabbits that are fed diets with high saturated and unsaturated lipid contents. Nevertheless, a previous study established that diets with high cholesterol content could have an effect on the integrity of the sperm cytoplasmic membrane in rabbits (Saez Lancellotti et al., 2010).

CONCLUSIONS. Taken together, our findings indicate that the addition of canola oil into a standard commercial feed, at the onset of puberty, during 12 weeks, can reduce the response time of male rabbit sexual behaviors such as olfactory exploration, chinning and second attempt at mounting when confronted with a young female stimulus, albeit no statistical differences could be found between groups in terms of the seminal parameters evaluated. Further studies are needed in domestic rabbit under farming conditions that allow the assessment for longer periods of time, the effect of diets with high vegetable oil content, in order to ascertain their effect on the development of behaviors associated with sexual maturity and its repercussion in the functional structure of the 
male reproductive organs. Similar research has been carried out in male rats (Medeiros Júnior et al., 2014). Information obtained in this field is also relevant for determining the benefits or disadvantages of diets supplemented with vegetable oil in terms of the reproductive efficiency of buck rabbits.

ACKNOWLEDGEMENTS. The authors wish to thank MVZ Veronica Alcántar for her help in the seminal evaluation and Dr. Fernando Flores Pérez for his help with the statistical analyses. The first author received a master's degree scholarship from CONACYT for a Master of Sciences in UNAM.

MEJÍA, H. N. G.; HERNÁNDEZ, E. J. \& PÉREZ-MARTÍNEZ, M. Parámetros seminales y conducta sexual en conejos de granja con dieta suplementada con aceite de canola al inicio de la pubertad. Int. J. Morphol., 36(1):59-62, 2018.

RESUMEN: Con el propósito de evaluar en conejos Nueva Zelanda blanca de granja el efecto de una dieta estándar suplementada con aceite de canola (obesogénica) sobre el comportamiento sexual y los parámetros espermáticos al inicio de la pubertad, se formaron dos grupos. Un grupo recibió una dieta consistente de $180 \mathrm{~g}$ al día de una dieta estándar comercial adicionada con $13 \mathrm{ml}$ de aceite de canola durante 12 semanas y al otro grupo (testigo) se le suministró $180 \mathrm{~g}$ por día de la misma dieta estándar sin aceite de canola. A partir de las 20 semanas de edad en cada individuo se midió el volumen seminal, la motilidad espermática en masa e individual, la concentración espermática por $\mathrm{mm}^{3}$ y se evaluaron la conducta de: exploración olfatoria, frotamiento del mentón (Chinning), primer intento de monta y segundo intento de monta. En las variables volumen seminal, conteo y porcentaje de motilidad espermática en masa e individual no hubo diferencia significativa entre ambos grupos $(\mathrm{P}>0,05)$. Con respecto al comportamiento sexual, el grupo suplementado con aceite vegetal presentó menor tiempo de respuesta a la hembra estímulo en las conductas de frotamiento del mentón, exploración olfatoria y segundo intento de monta con respecto al grupo testigo $(\mathrm{P}<0,01)$. Los datos obtenidos indican que la adición de aceite de canola a la dieta estándar de conejos al inicio de la pubertad durante 12 semanas aumenta el índice de masa corporal de los individuos y disminuye el tiempo de respuesta en las conductas de exploración olfatoria, de frotamiento del mentón y de segundo intento de monta al interaccionar con la hembra estímulo. Sin embargo, no modificó los parámetros seminales evaluados. Es necesario realizar otros estudios con el fin de evaluar en conejos sementales el beneficio o desventaja sobre su eficiencia reproductiva al utilizar diferentes porcentajes de inclusión en la dieta de otros aceites vegetales.

PALABRAS ClAVE: Conejo de granja; Pubertad; Semen; Conducta sexual; Aceite de canola.

\section{REFERENCES}

Alcántar, R. V. Inducción de la Ovulación con Monta Natural utilizando Machos Vasectomizados o Análogo Sintético de GnRH en Conejos Nueva Zelanda Blanco. Tesis de Licenciatura. Ciudad de México, FMVZ-UNAM, 2013. pp.3-71.

Alvariño, J. M. R. Reproductive Performance of Male Rabbits. In: Proceedings of the 7th World Rabbit Congress, 4-7 July 2000, Valencia, Spain, Volume A, 2000. pp.13-35.

Appleton, D. J.; Rand, J. S. \& Sunvold, G. D. Insulin sensitivity decreases with obesity, and lean cats with low insulin sensitivity are at greatest risk of glucose intolerance with weight gain. J. Feline Med. Surg., 3(4):211-28, 2001.

Aragón Hernández, J.; Suárez Sánchez, J. \& Pérez-Martínez, M. Morphometric characteristics of female reproductive organs of New Zealand rabbits with different body weight in peripuberal period of transition. Vet. Mex., 41(3):211$8,2010$.
Campbell, T. W. Clinical Chemistry of Mammals: Laboratory Animals and other Species. In: Thrall, M. A. (Ed.). Veterinary Haematology and Clinical Chemistry. Philadelphia, Lippincott Williams \& Wilkins, 2004. pp.463-78.

Caprio, M.; Fabbrini, E.; Isidori, A. M.; Aversa, A. \& Fabbri, A. Leptin in reproduction. Trends Endocrinol. Metab., 12(2):65-72, 2001.

Coppari, R.; Ichinose, M.; Lee, C. E.; Pullen, A. E.; Kenny, C. D.; McGovern, R. A.; Tang, V.; Liu, S. M.; Ludwig, T.; Chua, S. C. Jr.; Lowell, B. B. \& Elmquist, J. K. The hypothalamic arcuate nucleus: a key site for mediating leptin's effects on glucose homeostasis and locomotor activity. Cell Metab., 1(1):6372, 2005.

Fitzgerald, S. M.; Henegar, J. R.; Brands, M. W.; Henegar, L. K. \& Hall, J. E. Cardiovascular and renal responses to a high-fat diet in Osborne-Mendel rats. Am. J. Physiol. Regul. Integr. Comp. Physiol., 281(2):R547-52, 2001.

Fuentes, V. O.; Villagran, C. \& Navarro, J. Sexual behavior of male New Zealand white rabbits in an intensive production unit. Anim. Reprod. Sci., 80(1-2):15762, 2004.

Harcourt-Brown, F. M. \& Harcourt-Brown, S. F. Clinical value of blood glucose measurement in pet rabbits. Vet. Rec., 170(26):674, 2012.

Jenkis, J. R. Clinical Pathology. In: Meredith, A. \& Flecknell, P. (Eds.). BSAVA Manual of Rabbit Medicine and Surgery. ${ }^{\text {nd }}$ ed. Gloucester, British Small Animal Veterinary Association, 2006. pp.45-51.

Jiménez, P.; Serrano-Meneses, M. A.; Cuamatzi, E. \& González-Mariscal, G. Analysis of sexual behaviour in male rabbits across successive tests leading to sexual exhaustion. World Rabbit Sci., 20(1):13-23, 2012.

Medeiros Júnior, J. L.; Oliveira, F. A.; Silva, P. C.; Furriel, A.; Sampaio, F. J. \& Gregório, B. M. Lard and/or canola oil-rich diets induce penile morphological alterations in a rat model. Acta Cir. Bras., 29 Suppl. 1:39-44, 2014.

Moschos, S.; Chan, J. L. \& Mantzoros, C. S. Leptin and reproduction: a review. Fertil. Steril., 77(3):433-44, 2002.

Nelson, R. W.; Himsel, C. A.; Feldman, E. C. \& Bottoms, G. D. Glucose tolerance and insulin response in normal-weight and obese cats. Am. J. Vet. Res., 51(9):1357-62, 1990.

Rebollar, G. Inseminación Artificial en la Cunicultura Empresarial. En: Memorias del IV Ciclo Internacional de Conferencias en Cunicultura Empresarial. Texcoco, Universidad Autónoma Chapingo, 2006.

Ristic, N.; Stevanovic, D.; Nesic, D.; Ajdzanovic, V.; Rakocevic, R.; Jaric, I. \& Milosevic, V. Diet-induced obesity and ghrelin effects on pituitary gonadotrophs: Immunohistomorphometric study in male rats. Cell J., 17(4):711-9, 2016

Saez Lancellotti, T. E.; Boarelli, P. V.; Monclus, M. A.; Cabrillana, M. E.; Clementi, M. A.; Espínola, L. S.; Cid Barría, J. L.; Vincenti, A. E.; Santi, A. G. \& Fornés, M. W. Hypercholesterolemia impaired sperm functionality in rabbits. PLOS ONE, 5(10):e13457, 2010.

Schrauwen, P. \& Westerterp, K. R. The role of high-fat diets and physical activity in the regulation of body weight. Br. J. Nutr., 84(4):417-27, 2000.

Trayhurn, P. \& Bing, C. Appetite and energy balance signals from adipocytes. Philos. Trans. R. Soc. Lond. B Biol. Sci., 361(1471):1237-49, 2006.

Villagrán, C.; Navarro, J. \& Fuentes, V. O. Sexual exhaustion in White New Zealand male rabbits of different ages. Anim. Reprod. Sci., 76(3-4):251-5, 2003.

Zhang, X. J.; Chinkes, D. L.; Aarsland, A.; Herndon, D. N. \& Wolfe, R. R. Lipid metabolism in diet-induced obese rabbits is similar to that of obese humans. J. Nutr., 138(3):515-8, 2008.

\section{Corresponding Author: \\ Dr. Mario Pérez Martínez \\ Profesor Titular}

Departamento de Morfología

Laboratorio de Biología Tisular de la Reproducción

Facultad de Medicina Veterinaria y Zootecnia

Universidad Nacional Autónoma de México

Ciudad de México - MÉXICO

E-mail address: perezmtzmario@hotmail.com

Received: 08-05-2017

Accepted: 11-10-2017 